\title{
PROFESOR TOMASZ GIARO LAUREATEM NAGRODY FUNDACJI NAUKI POLSKIEJ
}

W dniu 7 grudnia 2011 r. na Zamku Królewskim w Warszawie odbyła się uroczystość wręczenia nagród Fundacji Nauki Polskiej za rok 2011. W obszarze nauk humanistycznych i społecznych otrzymał ja profesor Tomasz Giaro z Wydziału Prawa i Administracji Uniwersytetu Warszawskiego. W uzasadnieniu decyzji Fundacji podkreślono, że stanowi ona wyróżnienie „interdyscyplinarnej analizy kategorii prawdy w doktrynach prawa od antyku do współczesności, otwierającej nowe perspektywy rozumienia prawa jako jednego z fundamentów cywilizacji europejskiej". Laureat jest znany w środowisku polskich historyków prawa jako uczeń profesora Henryka Kupiszewskiego, jest jednym z najlepiej rozpoznawanych i najczęściej cytowanych w świecie współczesnych polskich romanistów. Specjalizuje się w badaniu zagadnień lokujących się na pograniczu studiów rzymskich źródeł prawnych oraz teorii i filozofii prawa. Owocem tak zorientowanych poszukiwań naukowych jest opublikowana w roku 2007 monografia Römische Rechtswahrheiten. Ein Gedankenexperiment, prezentująca rezultaty wyróżnione nagrodą Fundacji Nauki Polskiej. Przedstawione w tym obszernym dziele wyniki badań stopniowo stają się przedmiotem naukowej dyskusji. Okazują się ciekawym wzbogacaniem rozważań dogmatycznych ${ }^{1}$. Można zatem wyrazić przypuszczenie i życzenie, że przyznana Tomaszowi Giaro nagroda wzmocni zainteresowanie wynikającym z Jego badań przesłaniem, że „historia jest właściwie jedynym laboratorium dostępnym dla prawnika”. Wzmocni oddziaływanie powtarzanej przez Laureata myśli, że u podstaw troski o naukowość prawoznawstwa powinno być przekonanie, iż ,tym czym dla nauk empirycznych jest prawda, tym dla dogmatyki prawniczej jest tradycja"2.

WOJCIECH DAJCZAK (Poznań)

\section{KONFERENCJA KATEDR DOKTRYN POLITYCZNO-PRAWNYCH: „POLSKA I POLACY W OCZACH CUDZOZIEMCÓW. POLACY WOBEC CUDZOZIEMCÓW"}

W dniach 22-25 września 2011 r. w Kazimierzu Dolnym odbyła się konferencja na temat Polska i Polacy w oczach cudzoziemców. Polacy wobec cudzoziemców. Obradowali historycy idei, w większości pracownicy katedr i zakładów doktryn politycznoprawnych z uniwersyteckich wydziałów prawa, jednakże konferencja miała też wymiar międzynarodowy. Tradycja zjazdów „doktrynerów” jest podtrzymywana od czasu inicjatywy prof. dr. hab. Marka Maciejewskiego - pierwszy zjazd katedr, organizowany przez katedrę Uniwersytetu Wrocławskiego, odbył się w Świeradowie w 1998 r. Obecna konferencja to już 15. z kolei, organizatorem była Katedra Doktryn Polityczno-Prawnych UMCS. Na konferencji wygłoszono 26 referatów. Inaugurując konferencję, prodziekan Wydziału Prawa i Administracji UMCS, prof. dr hab.

${ }^{1}$ Por. T. Giaro, Rzymskie prawdy prawnicze. Eksperyment myślowy, w: Aurea praxis aurea teoria. Księga pamiqtkowa ku czci Profesora Tadeusza Erecińskiego, red. J. Gudowski, K. Weitz, Waszawa 2011, s. 2959-2982.

${ }^{2}$ Cytaty z wypowiedzi prof. T. Giaro, towarzyszącej uroczystości wręczenia nagrody FNP. 
Anna Przyborowska-Klimczak zwróciła uwagę, że postrzeganie innych jest bardzo istotnym składnikiem rzeczywistości politycznej, że stanowi ważny problem, zwłaszcza gdy chodzi o prawa mniejszości, ale wiąże się też z licznymi regulacjami prawnymi, dotyczącymi prawa pobytu, swobody podróżowania etc. Gości przywitał też prof. dr hab. Marek Kuryłowicz, dyrektor obchodzącego 40-lecie Instytutu Historii i Teorii Państwa i Prawa, podkreślając, że Wydział Prawa i Administracji UMCS jest jednym z ostatnich wydziałów, który zachował strukturę instytutowa. W skład wspomnianego Instytutu wchodzi Katedra Historii Państwa i Prawa, Katedra Teorii i Filozofii Prawa oraz Katedra Doktryn Politycznych i Prawnych. Kierownik tej ostatniej, prof. dr hab. Lech Dubel uzasadniał wybór tematu konferencji, między innymi zaznaczając, że sformułowanie „Polacy” było konieczne, poniewaź zasadnie można debatować nad tym, kiedy moźna mówić o narodzie, zważywszy rozmaite koncepcje i definicje narodu we współczesnej debacie politologicznej.

Najogólniej rzecz biorąc, wygłoszone referaty można klasyfikować w rozmaity sposób. Najprostsze kryterium merytoryczne, to znaczy według tego, czy przedstawiały opinie Polaków o innych, czy cudzoziemców o Polakach, pozwala stwierdzić, że te ostatnie były liczniejsze, a dotyczyły zarówno czasów najnowszych, jak i czasów historycznych poczynając od Średniowiecza. Mieściły się w nim referaty: prof. Marka Maciejewskiego (UWr) - Polska i Polacy w pogladach Adolfa Hitlera; prof. Mikołaja Dżawachiszwili (Uniwersytet Państwowy im. Iwane Dżawachiszwili w Tbilisi) - Polska i Polacy w oczach wybitnych dzialaczy gruzinskich do lat dwudziestych XX wieku; dr. Zaruba Jawaszwili (UP im. I. Dżawachiszwili w Tbilisi) - Obraz Polaków u Gruzinów: wojna sierpniowa i solidarność polsko-gruzińska; dr. hab. Piotra Kimli (UJ) - Niewolnik pańszczyźniany w XVIII-wiecznej Rzeczypospolitej w świetle wybranych świadectw cudzoziemskich; dr. Pawła Sydora (UŁ) - „Biała” Polska i „Czerwoni" Polacy. Polskość w oczach Lwa Dawidowicza Trockiego; dr. hab. Mirosława Sadowskiego (UWr) - Polska i Polacy doby Renesansu w oczach cudzoziemców; dr. Radosława Antonówa (UWr) - Polska i Polacy w myśli i działalności Michala Bakunina; dr Marty Baranowskiej (UMK) - Jan Jakub Rousseau o narodzie i Polakach; dr. Tomasza Schefflera - Polska w planach przedstawicieli konserwatywnej opozycji antyhitlerowskiej; dr Anny Klimaszewskiej (UG) - Louls Pierre Eduard Bignon a sprawa polska; mgr. Andrzeja Madeji (UMK) - Adenauer wobec Polski i Polaków i mgr Marty Maj (UAM), Obraz Polaków w twórczości Jules 'a Micheleta. Druga grupa referentów przedstawiła odwrotną perspektywę: wyobrażenia Polaków o cudzoziemcach. Tutaj należy wymienić referaty prof. UJ dr hab. Barbary Stoczewskiej - Wizerunek Ukrainca w polskiej myśli politycznej-perspektywa historyczna oraz wspótczesne odniesienia; prof. UWr. dr. hab. Macieja Marszała - Elity polityczne Drugiej Rzeczypospolitej wobec Wlochów i wloskiego faszyzmu; dr. Zbigniewa Markwarta (Politechnika Radomska) - Państwa zaborcze i ich polityka wobec Polski w pogladach stronnictwa realistów; dr. Jakuba Skomlała (UŁ) - Od obcości do wspólnoty sarmackiej. Ruś i jej mieszkańcy w ujęciu kronikarzy polskiego średniowiecza; dr. Przemysława Dąbrowskiego (UG) - Obraz Litwinów - glównych przedstawicieli litewskiego odrodzenia narodowego w oczach Polaków - mieszkańców bylego Wielkiego Księstwa Litewskiego na przelomie XIX i XX wieku; szeroko zakrojony referat dr. Artura Łuszczyńskiego i dr Małgorzaty Łuszczyńskiej (UMCS) - Obraz sqsiadów w oczach wybranych przedstawicieli czeskiej myśli politycznej w XIX i XX wieku, w którym autorzy zaprezentowali czeski obraz Polski i Polaków na tle stosunku Czechów do Słowaków, Niemców i Węgrów; dr. Błażeja Sajduka - Charakter narodowy Niemców i Rosjan w pismach Jana Karola Kochanowskiego (1869-1949); a także mgr. Macieja Indian-Pykno (UMK) - Fizjokratyzm oczyma polskich przedstawicieli myśli polityczno-prawnej. Ostatnia grupa zajmowała się jednym i drugim problemem albo też pokazywała praktyczne konsekwencje takich obrazów czy to ze strony cudzoziemców, czy Polaków. Należałoby tutaj wskazać referaty prof. dr. hab. Tarasa Andrusiaka (Uniwersytet Iwana Franki we Lwowie) - Lwów jako centrum rozwoju polskiej i ukraińskiej myśli prawniczej", prof. UW dr. hab. Adama Bosiac- 
kiego - Polscy prawnicy w Rosji przed 1917 rokiem: koncepcje teorii i praktyki prawa na przykładzie postaci Aleksandra Lednickiego, Leona Petrażyckiego i Gabriela Szerszeniewicza; dr. hab. Arkadego Rzegockiego (UJ) - Rycerze wolności. Przypadek Polskiego Uniwersytetu na Obczyźnie; dr. Przemysława Krzywoszyńskiego (UAM) - Zagadnienia narodowościowe w wybranych polskich plebiscytach i referendach (1920, 1921, 1946); dr. Marcina Niemczyka (UR), Sladami doktrynalnych spotkań Milovana Djilasa z Polskq.

Prima facie tematyka mogła wydać się nazbyt odległa od klasycznej myśli politycznoprawnej. Jednakże warto odnotować, że obraz cudzoziemców, bez względu na to, czy z gruntu fałszywy i stereotypowy, czy też odpowiadający rzeczywistości, ma istotne znaczenie dla formułowanej bądź praktykowanej doktryny politycznej. Stereotypy bardzo często uzasadniały określone idee polityczne. Postrzeganie Słowaków jako Czechów dawało dobrą pozycję dla rządów Masaryka, co bardzo wyraźnie pokazali w swoim referacie dr dr Małgorzata i Artur Łuszczyńscy. Wpływ sposobu postrzegania był często przyczyną takiej, a nie innej polityki, albo odwrotnie - tworzono obraz, by usprawiedliwić określoną politykę. $Z$ drugiej strony ważnym elementem dyskusji był problem definicji narodu. W doktrynie politycznej bardzo często przyjmowana definicja narodu (w zależności od zakładanej podstawy więzi narodowejetnicznej, kulturowej czy państwowo-politycznej) ma bardzo duże znaczenie dla treści ustrojowych. Ożywiona dyskusja toczyła się na przykład wokół pojmowania narodu jako ,jedności obywateli", w wydaniu czy to Rousseau, czy Micheleta. Pokazano obrazy pozytywne Polaków, ale i negatywne, na przykład niezwykle interesujący obraz wsi polskiej i negatywny wizerunek chłopa polskiego w referacie dr. hab. Piotra Kimli, Niewolnik pańszczyźniany w XVIII-wiecznej Rzeczpospolitej w świetle wybranych świadectw cudzoziemskich. Jeden $\mathrm{z}$ referentów, mianowicie dr Przemysław Krzywoszyński, mówił o wadze stereotypów w praktyce politycznej, szczególnie podczas agitacji przy okazji referendów.

Sformułowanie „obraz Polaków” dawało szerokie pole do podjęcia badań nie tylko nad tym jak Polacy byli postrzegani w dobie państwa narodowego, ale także przedtem, na przykład w głębokim Średniowieczu, chociaż oczywiście używanie terminu „naród”, a nawet terminu „Polacy” budzić może - w świetle współczesnych badań nad narodami i nacjonalizmami wątpliwości, co zresztą już na początku zasygnalizował prof. Lech Dubel.

Uwagi generalne są dwie: po pierwsze, spojrzenie na siebie oczyma obcych wskazuje, że nie zawsze konfrontacja jest jednoznaczna; po drugie, niewatpliwie historyk idei ma przed sobą trudne zadanie: musi i powinien określić, co rozumie przez pojęcie narodu, w jakim kontekście go używa itd. Pod tym względem konferencja z pewnością poszerzała horyzonty badawcze historyków doktryn, ale też pokazała, że zagadnienie warte jest dalszych badań.

W trakcie konferencji poruszono także inny problem - zwrócono mianowicie uwagę na konieczność stworzenia forum, które mogłoby artykułować i w sposób oficjalny reprezentować specjalność, jaką są doktryny politycznoprawne. Ideę tę przedstawili zgromadzonym prof. Zbigniewa Rau (UL) oraz prof. Marek Maciejewski (UW). Zdecydowano powołać do życia i zarejestrować Polskie Towarzystwo Myśli Politycznej. Przy okazji konferencji odbyło się zatem zebranie założycielskie, uchwalono statut oraz wybrano zarząd. Przewodniczącym został prof. UWr Maciej Marszał, członkami zarządu dr Anna Machnikowska (UG), prof. UŁ Maciej Chmieliński i dr Jarosław Kostrubiec (UMCS), a sekretarzem dr Michał Urbańczyk (UAM). Zarząd podejmie starania o zarejestrowanie Towarzystwa.

Poza częścią oficjalną nie zabrakło atrakcji turystycznej, jaką była przeprawa na druga stronę Wisły w celu zwiedzenia ruin i pozostałości zamku w Janowcu, niegdyś należącego do rodu Firlejów, z przepięknymi widokami na Wisłę. Był to najdłużej pozostający w rękach prywatnych zamek w PRL - ostatni jego właściciel, Leon Kozłowski, sprzedał zamek Muzeum Nadwiślańskiemu w 1975 r. Samo miejsce odbywania konferencji w Kazimierzu Dolnym Dom Pracy Twórczej Dziennikarzy - było niezwykłe, mieściło się tuż obok słynnej Kuncewiczówki, którą uczestnicy konferencji mogli zwiedzić w przerwach między obradami. Organi- 
zacja konferencji była wzorcowa, należy tu z uznaniem podkreślić starania prof. Lecha Dubela i pracowników UMCS. Materiały mają być opublikowane w „Annales UMCS”. Natomiast zmiany w sposobie finansowania szkolnictwa wyższego wzbudziły niepokój, czy uda się kontynuować tradycje konferencji, które dla rozwoju młodych kadr z pewnością mają ogromne znaczenie. Ten znak zapytania i niepokój o przyszłość towarzyszył ostatnim refleksjom uczestników konferencji.

MARIA ZMIERCZAK (Poznań)

\section{KONFERENCJA NAUKOWA: „WYBITNI PRAWNICY NA UNIWERSYTECIE WROCLAWSKIM”}

W roku 2011 obchodzony był jubileusz 200-lecia fakultetu prawniczego na Uniwersytecie we Wrocławiu. Wydział ten powstał w roku 1811, kiedy rozkazem Fryderyka Wilhelma III przeniesiono Uniwersytet Viadrina z Frankfurtu nad Odrą do Wrocławia i połączono z wrocławską Leopoldina, tworząc tym samym uniwersytet państwowy. Z tej okazji w PolanicyZdroju między 27 a 29 października 2011 r. odbyła się - zorganizowana przez Instytut Historii Państwa i Prawa oraz Katedrę Doktryn Politycznych i Prawnych Wydziału Prawa, Administracji i Ekonomii Uniwersytetu Wrocławskiego - konferencja naukowa Wybitni prawnicy na Uniwersytecie Wroclawskim, analizująca dorobek intelektualny prawników związanych z tą uczelnią. Pomysłodawcami konferencji byli prof. Maciej Marszał z Katedry Doktryn Politycznych i Prawnych oraz dr Jacek Przygodzki, reprezentujący Instytut Historii Państwa i Prawa.

Obrady, prowadzone przez kierownika Katedry Doktryn Politycznych i Prawnych prof. Marka Maciejewskiego oraz dyrektora Instytutu Historii Państwa i Prawa prof. Mariana J. Ptaka, podzielone były na dwie wyraźne części. Pierwsza odnosiła się do dokonań prawników związanych z wrocławskim środowiskiem naukowym w okresie prusko-niemieckim, nie ograniczając się bynajmniej do ukazania dorobku środowiska niemieckich uczonych, lecz przybliżając także sylwetki wybitnych później Polaków, którzy zdobywali wykształcenie prawnicze we Wrocławiu. Uwaga referentów skupiła się zatem na postaciach Johanna Friedricha Meistera (prof. Marian J. Ptak), Wojciecha Korfantego (prof. Maciej Marszał), Ernsta Ludwiga von Belinga (prof. Józef Koredczuk), Wojciecha Trąmpczyńskiego (mgr Paweł Fiktus), Güntera Schmöldersa (prof. Tomasz Kruszewski), a także Hansa Helfritza (dr Jacek Przygodzki). Z kolei dr Tomasz Dolata przedstawił syntetycznie kariery wrocławskich profesorów prawa w latach 1811-1900. Druga część obrad natomiast koncentrowała się na wybitnych i zasłużonych na różnych polach aktywności prawnikach, mających związki z Uniwersytetem Wrocławskim w okresie powojennym. Rozpoczęła ją prezentacja osiagnięć znakomitego karnisty i rektora Uniwersytetu w latach 1959-1962, prof. Witolda Świdy (dr Andrzej Pasek), zakończyło zaś omówienie twórczości naukowej jego córki - znawczyni procedury karnej - prof. Zofii Świdy, zmarłej nagle w lutym $2011 \mathrm{r}$. (dr Paweł Wiązek). Pozostałe referaty poświęcone zostały prof. Karolowi Joncy (dr hab. Mirosław Sadowski), prof. Janowi Baszkiewiczowi (prof. Marek Maciejewski), prof. Kazimierzowi Orzechowskiemu (prof. Piotr Jurek), prof. Andrzejowi Stelmachowskiemu (mgr Piotr Szymaniec i mgr Paweł Fiktus) oraz Aleksandrowi Małachowskiemu (mgr Marta Mackiewicz). 